DOI: https://doi.org/10.47405/mjssh.v6i5.798

\begin{tabular}{|c|c|}
\hline$m_{1}=$ & Malaysian Journal of Social Sciences and Humanities (MJSSH) \\
\hline Malaysian Journal of & Volume 6, Issue 5, May 2021 \\
\hline (MJ-SSH) & e-ISSN : 2504-8562 \\
\hline & $\begin{array}{l}\text { Journal home page: } \\
\text { www.msocialsciences.com }\end{array}$ \\
\hline
\end{tabular}

\title{
Kepuasan Kerja dan Burnout Guru Pendidikan Jasmani di Daerah Langkawi
}

\author{
Nur Hamizah Binti Zainudin'1, Tajul Arifin Bin Muhamad ${ }^{1}$ \\ ${ }^{1}$ Fakulti Pendidikan, Universiti Kebangsaan Malaysia (UKM) \\ Correspondence: Nur Hamizah Binti Zainudin (P101230@siswa.ukm.edu.my)
}

\begin{abstract}
Abstrak
Kepuasan kerja yang tinggi amat penting untuk mengelakkan terjadinya gejala burnout dalam kalangan guru di sekolah. Kajian ini bertujuan untuk mengenal pasti tahap kepuasan kerja dan tahap burnout guru Pendidikan Jasmani di Daerah Langkawi. Selain itu, kajian ini juga bertujuan untuk mengenal pasti hubungan antara kepuasan kerja dan burnout guru PJ. Hasil kajian ini mungkin dapat memberi gambaran tentang fenomena burnout dalam kalangan pendidik terutamanya guru PJ. Kajian ini merupakan kajian tinjauan yang melibatkan seramai 101 orang responden serta menggunakan borang soal selidik Job Descriptive Index (JDI) dan Maslach Burnout Inventory (MBI) sebagai instrumen kajian. Data yang dikumpul telah dianalisis dengan menggunakan perisian Statistical Packages for Social Science (SPSS) versi 22.0. Secara keseluruhannya, tahap kepuasan kerja guru berada pada tahap yang tinggi. Dimensi penyeliaan, rakan sekerja, gaji dan kerja itu sendiri mencatatkan tahap kepuasan tinggi kecuali dimensi kenaikan pangkat yang mencatatkan tahap sederhana. Tahap burnout guru juga berada pada tahap sederhana bagi sub skala keletihan emosi, rendah bagi subskala depersonalisasi dan tinggi bagi sub skala pencapaian peribadi. Hasil kajian ujian analisis korelasi turut mendapati terdapat hubungan negatif yang lemah dan signifikan antara kepuasan kerja dengan dua sub skala burnout iaitu keletihan emosi dan depersonalisasi. Gejala burnout boleh dielakkan jika guru mendapat kepuasan kerja yang sepatutnya dengan mengekalkan persekitaran kerja yang menyeronokkan dan tekanan kerja yang minimum. Pihak atasan sekolah perlu lebih peka dengan kebajikan guru yang mengajar supaya kualiti pendidikan lebih terjamin bagi membantu kemenjadian murid terutama dalam menempuhi pembelajaran abad ke-21.
\end{abstract}

Kata kunci: kepuasan kerja, burnout, guru pendidikan jasmani, tekanan guru, Langkawi

\section{Job Satisfaction and Burnout among Physical Education Teachers in Langkawi District}

\begin{abstract}
High level of job satisfaction is important in order to avoid the burnout phenomenon among teachers in school. The purpose of this study is to identify the level of job satisfaction and the level of burnout among the Physical Education teachers in Langkawi District. Apart from that, the research is to identify the relationship between the job satisfaction and Physical Education teachers' burnout. The research findings may illustrate clearer perception specifically on PE teachers' burnout phenomenon. This research comprises 101 respondents and was conducted through a survey method using online questionnaire. The research instrument was developed based on the Job Descriptive Index (JDI) and Maslach Burnout Inventory (MBI). Data collected was analysed with the Statistical Packages for Social Science (SPPS) 22.0 version. Overall, results showed that the teachers' job satisfaction was at a high
\end{abstract}


level. The dimension for supervision, colleagues, salary and the job scope were recorded at a higher level except for job promotion which were at moderate level. As for the emotional exhaustion subscale, teachers' burnout level was moderate while the depersonalisation and personal achievement were low and high respectively. The results of the correlation analysis also showed that there was a weak negative relationship yet significant between job satisfaction and the main two burnout subscale which are emotional exhaustion and depersonalisation. Burnout phenomenon can be avoided if teachers receive sufficient job satisfaction with a good working environment and minimum work load. The school administrators need to be more aware regarding teachers' welfares in order to preserve the education quality. Thus, producing holistic students to compete in the $21^{\text {st }}$ century learning.

Keywords: job satisfaction, burnout, physical education teachers, teachers' stress, Langkawi

\section{Pengenalan}

Pengenalan kepada kurikulum baharu dan pembelajaran abad ke-21 menjadikan guru semakin komited dalam melakukan tugas-tugas harian. Semua guru memainkan peranan penting dalam melaksanakan pembelajaran abad-21 sekali gus merealisasikan misi dan visi KPM (Rusdin \& Ali, 2019). Perubahan dasar pendidikan menjadikan bebanan kerja guru bertambah sehingga menyebabkan tekanan. Tekanan kerja yang dialami oleh guru sangat membimbangkan sehingga ada segelintir guru mengambil keputusan untuk menamatkan perkhidmatan dalam bidang perguruan, bersara dengan lebih awal atau menarik diri sepenuhnya dalam melaksanakan tugas yang diberi. Kenyataan ini disokong oleh Sipon (2010) yang mendapati, tekanan telah menyebabkan guru memilih untuk bersara lebih awal di samping memberi kesan kepada kepuasan kerja guru dan produktiviti guru. Selain itu, menurut Ineme dan Ineme (2016), guru juga menjadi tidak bersemangat untuk mengajar di sekolah disebabkan oleh tekanan kerja yang tidak terkawal.

Cabaran kerja dan komitmen guru terhadap tugas menjadikan guru bekerja dalam keadaan tertekan serta menanggung beban kerja yang agak berat. Tanggungjawab guru dalam membantu kemenjadian murid mengakibatkan konflik sehingga menyebabkan guru mengalami tekanan (Ismail et al., 2016). Statistik yang dikeluarkan oleh pihak KPM menunjukkan 2123 (4.4\%) daripada 48,258 pendidik mengalami tekanan kerja pada tahap sederhana dan tinggi (Berita Harian, 2018). Oleh itu, ramai guru yang mengalami tekanan kerja tidak mendapat kepuasan kerja yang sepatutnya. Perkara ini dikhuatiri boleh mendatangkan fenomena yang mengancam kualiti kerja guru sehingga mereka mengalami burnout. Secara umumnya, kepuasan kerja boleh ditakrifkan sebagai satu perasaan positif berkaitan emosi seseorang yang dihasilkan dari pendapat individu itu sendiri terhadap pekerjaan atau pengalaman kerja (Locke, 1976) manakala burnout pula adalah satu perasaan kelesuan fizikal dan emosi yang dirasakan sehingga menyebabkan individu terlalu penat dan memerlukan rehat yang secukupnya (Anjang \& Bakar, 2019).

Kepuasan kerja merupakan asas utama dalam sesebuah organisasi bagi menghasilkan kualiti kerja yang cemerlang serta membantu dalam kemenjadian murid. Apabila guru tidak berpuas hati terhadap sesuatu perkara, kepuasan kerja guru akan berkurang (Ismail et al.,2016). Guru tidak mendapat kepuasan kerja kerana tekanan dan bebanan tugas yang melampau sehingga mereka tidak dapat fokus pada kerja hakiki dan hilang rasa keseronokan untuk mengajar. Faktor dalaman dan faktor luaran juga memberikan pengaruh yang positif dan negatif kepada tahap kepuasan kerja guru (Kariming \& Ambotang, 2018). Secara psikologinya, faktor seperti gaji, penyelia dan rakan sekerja juga mempengaruhi kepuasan kerja guru dalam sesuatu organisasi (Okeke \& Mtyuda, 2017; Hassan \& Wahab, 2017; Rahman \& Mansor, 2018).

Maslach dalam Teles et. al (2020) membahagikan burnout kepada tiga dimensi utama iaitu keletihan emosi, depersonalisasi dan pencapaian peribadi. Jika seseorang individu mengalami keletihan emosi dan depersonalisasi pada tahap tinggi serta rendah pada pencapaian peribadi, maka individu itu berpotensi mengalami burnout. Kajian lepas berkaitan burnout dalam kalangan guru menunjukkan dapatan negatif yang boleh menganggu proses pengajaran dan pembelajaran. Szabo \& Jagodics (2019) 
mendapati guru mengalami tahap burnout sederhana secara keseluruhannya kerana mencatatkan skor sederhana tinggi bagi dimensi keletihan emosi dan tahap sederhana pada dimensi depersonalisasi dan pencapaian peribadi. Kerjaya guru yang terpaksa berhadapan dengan pelbagai ragam pelanggan seperti murid, ibu bapa dan pihak atasan menyebabkan guru rasa terbeban sekali gus mengganggu emosi guru. Motivasi murid juga boleh terjejas apabila guru mengalami burnout pada dimensi keletihan emosi sehingga mengganggu kualiti pengajaran guru tersebut (Shen et al., 2015).

Guru Pendidikan Jasmani juga tidak terlepas dengan pertambahan kerja dan bebanan kerja pada zaman sekarang. Penggabungan kelas, tugas yang bertindan di samping pemberian waktu mengajar yang banyak kepada guru PJ oleh pihak pentadbiran menyebabkan guru PJ terbeban dengan masalah tersebut (Awang, 2012). Menurut Grant dalam Ali et al. (2017), guru PJ mempunyai peranan yang penting dalam memastikan perlaksanaan subjek Pendidikan Jasmani di sekolah berkesan dan dapat dilaksanakan dengan baik. Oleh itu, apabila guru PJ terbeban dengan tugas akademik dan bukan akademik, mereka akan menjadi tertekan sehingga mengganggu kepuasan kerja sekali gus menyebabkan burnout.

Apabila guru PJ tidak mendapat kepuasan kerja yang sepatutnya serta mengalami gejala burnout, maka perkara ini akan memberikan kesan yang negatif kepada kualiti kerja guru tersebut. Menurut Zulkafli \& Mahbob (2020) jika seseorang pekerja tidak mendapat kepuasan kerja yang diinginkan, maka mereka akan bertindak negatif kepada organisasi tersebut dan tidak memberikan komitmen seratus peratus terhadap bidang tugas masing-masing. Oleh itu, dapatlah diakui bahawa kepuasan kerja dan burnout saling mempunyai perkaitan dalam menentukan kecemerlangan sesebuah organisasi (Mahmod et al., 2018). Oleh itu, fenomena kepuasan kerja dan burnout ini sangat dikhuatiri boleh menjejaskan motivasi guru sekaligus memberikan kesan kepada guru itu sendiri, murid dan sekolah.

\section{Pernyataan masalah}

Tekanan demi tekanan serta bebanan kerja yang melampau menyebabkan guru tidak mendapat kepuasan kerja seperti yang diharapkan. Apabila guru tertekan dan kepuasan kerja tidak dikecapi, hal ini akan menyebabkan guru mengalami gejala burnout jika tidak diberi perhatian secara serius. Guru PJ juga tidak terkecuali dengan permasalahan tersebut walaupun persekitaran kerja mereka sepatutnya lebih menyeronokkan kerana lebih melibatkan aktiviti fizikal dan jasmani di luar bilik darjah. Persekitaran kerja yang tidak inovatif boleh membawa kepada tekanan dan guru berpotensi tinggi untuk mengalami burnout (Badawy, 2015).

Skop kerja guru PJ memerlukan usaha yang gigih semasa berkomunikasi di padang dalam mengawal tingkah laku murid yang pelbagai. Risiko ketika mengendalikan peralatan sukan yang berbahaya memaksa guru PJ menjadi lebih tegas ketika mengajar tetapi dalam masa yang sama masih mengekalkan budi bahasa semasa berhadapan dengan pelbagai karenah murid. Hal ini menyebabkan emosi dan fizikal guru PJ sedikit terganggu dan perkara ini perlu diberikan perhatian bagi melihat sama ada guru PJ mendapat kepuasan kerja yang sepatutnya ataupun tidak. Persepsi pentadbir yang beranggapan tugas kerja guru PJ sangat menyeronokkan dan mereka tidak mengalami tekanan kerana hanya mengajar murid bermain di padang perlu diubah kerana ramai beranggapan guru PJ tidak tertekan dan psikologi mereka tidak terganggu. Perkara ini perlu mendapat tindakan yang sewajarnya oleh pihak pengurusan dalam pembahagian tugas dan kerja kepada guru di sekolah.

Walau bagaimanapun, kajian-kajian lepas yang dijalankan lebih berfokus kepada guru secara menyeluruh tanpa memberikan perhatian bagi sesuatu mata pelajaran khususnya guru PJ. Kepuasan kerja dan tahap burnout guru PJ sering kali dipandang enteng ramai pihak. (Vousiopoulos, 2019). Secara perbandingannya, banyak kajian dijalankan hanya berfokus kepada guru subjek lain tetapi kurang perhatian diberikan kepada guru PJ sedangkan mereka lebih terdedah kepada keletihan emosi dan fizikal disebabkan kerja yang melibatkan perantaraan secara langsung dengan murid di luar bilik darjah. Melihat kepada pengetahuan sedia ada berkaitan kepuasan kerja dan burnout dalam kalangan guru PJ yang agak terhad terutamanya di Malaysia, satu kajian perlu dilakukan bagi mengenal pasti 
tahap kepuasan kerja dan burnout guru PJ serta melihat hubungan antara kedua-dua pembolehubah tersebut.

\section{Objektif Kajian}

Isu tentang pengaruh kepuasan kerja dan burnout dalam kalangan guru PJ di Malaysia sentiasa dibincangkan tetapi tiada kajian ilmiah terbaru dijalankan bagi menjawab isu tersebut. Persoalan yang timbul ialah apakah tahap kepuasan kerja guru dan tahap burnout dalam kalangan guru PJ di daerah Langkawi. Selain itu, adakah terdapat hubungan antara kepuasan kerja guru dengan tahap burnout guru tersebut. Sehubungan dengan itu, kajian ini diperlukan untuk mengenal pasti tahap kepuasan kerja dan tahap burnout guru Pendidikan Jasmani di Daerah Langkawi. Objektif kajian secara khususnya adalah untuk:

i. $\quad$ Mengenal pasti tahap kepuasan kerja guru PJ di Daerah Langkawi

ii. $\quad$ Mengenal pasti tahap burnout guru PJ di Daerah Langkawi.

iii. Mengenal pasti hubungan antara kepuasan kerja dan burnout guru PJ di Daerah Langkawi.

\section{Sorotan Literatur}

Secara teorinya, kepuasan boleh ditakrifkan sebagai satu perasaan puas atau seronok apabila melakukan sesuatu perkara. Kepuasan kerja guru terbahagi kepada lima dimensi utama iaitu kerja itu sendiri, gaji, penyeliaan, kenaikan pangkat dan rakan sekerja. Burnout pula merupakan satu simptom yang dialami oleh individu yang mengalami tekanan sehingga menyebabkan mereka rasa terlalu penat atau lesu dan boleh mengganggu kualiti kerja seharian. Gejala burnout boleh dialami oleh semua individu bagi setiap peringkat profesion sama ada bagi pekerjaan yang mempunyai tekanan tinggi atau tidak. Konsep burnout telah diperkenalkan dalam bidang perubatan oleh Herbert Freudenberger (1974). Beliau menggambarkan burnout sebagai satu perasaan lesu atau penat yang melampau akibat tekanan yang berterusan bagi seseorang individu.

Maslach et al. (2001) membahagikan burnout kepada tiga subskala iaitu keletihan emosi (emotional exhausted), depersonalisasi (depersonalization) dan pengurangan pencapaian peribadi (reduce personal accomplish). Ketiga-tiga subskala ini mewakili beberapa aspek yang berbeza. Keletihan emosi terjadi apabila guru merasakan sesuatu kerja itu terlalu berat sehingga menjadi penat dari segi emosi dan psikologi. Bagi aspek depersonalisasi pula, gangguan psikologi terhadap individu akan menyebabkan perubahan tingkah laku negatif seperti meninggikan suara, bersikap kasar dan sinis terhadap murid. Aspek pencapaian kendiri pula menjurus kepada penilaian peribadi yang negatif dan merasakan bahawa diri mereka tidak melaksanakan tanggungjawab dengan sebaik mungkin.

\section{Teori Kajian}

Teori yang digunakan untuk kepuasan kerja dalam kajian ini ialah Teori Dua Faktor Herzberg. Teori ini telah diperkenalkan oleh seorang ahli psikologi dari Amerika Syarikat iaitu Frederick Irving Herzberg. Beliau menyatakan bahawa terdapat beberapa faktor yang mempengaruhi kepuasan kerja di tempat kerja. Menurut Herzberg dalam Ishak (2015), dua jenis faktor yang telah dikenal pasti ialah faktor luaran (hygiene factors) dan faktor penyebab kepuasan (motivator factors). Faktor luaran melibatkan gaji, kerja itu sendiri, pengurusan, penyeliaan dan rakan sekerja. Kepuasan kerja berkait secara langsung dengan dengan teori motivasi kerana setiap individu memerlukan dorongan atau sokongan untuk mencapai satu matlamat atau kejayaan yang diingini (Affendi, 2014).

Kajian ini dilakukan dengan berdasarkan Teori Conservation of Resources (COR) untuk menjangkakan burnout yang diasaskan oleh Dr. Stevan E. Hobfoll pada awal tahun 1989. Berdasarkan teori tersebut, seseorang individu mengalami tekanan disebabkan oleh keadaan mental yang mendapat amaran dari badan bahawa beberapa perkara negatif akan berlaku disebabkan oleh kehilangan sumber tenaga dan 
badan tidak mampu untuk menggantikan sumber tenaga yang hilang tersebut dengan sumber yang baru. Oleh itu, individu tersebut akan merasa tertekan sehingga menyebabkan diri mengalami burnout.

\section{Kajian-kajian lepas}

Kepuasan kerja dalam kalangan guru menjadi isu hangat seiring dengan perubahan dasar yang telah dilakukan oleh KPM. Beberapa kajian dijalankan dalam kalangan guru bagi mengetahui faktor yang mempengaruhi kepuasan kerja mereka. Antara dapatan yang diperoleh mendapati faktor kerja itu sendiri dan suasana kerja penting dalam menyumbang kepada kepuasan kerja seseorang individu. Hal ini dibuktikan dalam kajian (Mohamad \& Yaacob, 2013; Mansor et al., 2015; Sulaiman, 2014) yang mendapati dimensi kerja menjadi elemen utama yang memberikan kepuasan kerja bagi diri seseorang diikuti dimensi rakan sekerja dan pihak atasan.

Pengaruh rakan sekerja juga memberikan impak yang besar dalam menentukan kepuasan kerja seseorang. Ini kerana sikap toleransi antara satu sama lain dapat memberikan kelegaan kepada seseorang individu yang terpaksa berhadapan dengan ramai orang seperti guru. Menurut Smetackova et al. (2019), faktor rakan sekerja merupakan faktor paling utama yang mempengaruhi kepuasan kerja dalam kalangan guru. Dapatan kajian ini disokong oleh kajian Hassan dan Wahab (2017) dalam satu kajian di sekolah menengah harian berprestasi rendah di Bangsar. Hasil kajian mendapati dimensi rakan sekerja merupakan penyumbang utama guru mendapat kepuasan kerja yang tinggi.

Guru sering kali mengalami keletihan emosi dan fizikal serta berisiko untuk mengalami burnout. Kajian yang dijalankan oleh Matiang'i et al. (2016) serta Jamaludin dan You (2019) mendapati guru mengalami burnout pada sub skala keletihan emosi sehingga mengurangkan pencapaian peribadi dan menghadapi depersonalisasi. Tekanan masyarakat terhadap peranan kerja guru secara berterusan menyebabkan guru mengalami gejala burnout dalam aspek keletihan emosi sehingga memberikan impak yang negatif kepada keadaan sekeliling mereka (Spittle et al., 2015). Dapatan ini juga selari dengan kajian yang dijalankan oleh Al-Adwan dan Al-Khayat (2017) yang mendapati tekanan daripada ibu bapa murid merupakan antara punca berlakunya burnout dalam kalangan guru. Ramai ibu bapa meletakkan harapan yang tinggi kepada guru dalam memenuhi tuntutan terhadap anak-anak mereka sehingga menyebabkan guru mengalami tekanan psikologi sehingga menyebabkan burnout.

Faktor persekitaran dan iklim kerja guru juga menyumbang kepada berlakunya burnout. Kajian yang dijalankan oleh Ryan et al. (2017) di Amerika Syarikat mendapati gejala burnout berlaku disebabkan oleh persekitaran kerja yang membosankan sehingga guru memilih untuk bertukar tempat kerja atau berhenti dari profesion tersebut. Tsigilis et al. (2011) membandingkan tahap burnout guru PJ sekolah rendah dan sekolah menengah di Greece. Dapatan kajian mendapati, guru PJ sekolah rendah mengalami keletihan emosi yang lebih tinggi berbanding guru PJ sekolah menengah. Kajian Kroupis et al. (2019) pula melaporkan burnout guru berada pada tahap membimbangkan. Hasil dapatan ini berkemungkinan disebabkan oleh tiada sokongan daripada pihak atasan serta penggabungan murid yang terlalu ramai bagi setiap kelas di samping keadaan sosioekonomi yang tidak menentu sehingga menjejaskan persekitaran pekerjaan mereka.

Dapatan kajian-kajian lepas mendapati terdapat hubungan negatif yang lemah antara kepuasan kerja dengan burnout (Ooi \& Abdullah, 2016; Esfandiari \& Kamali, 2016). Hasil kajian ini menyokong teori oleh Maslach yang menyatakan bahawa jika seseorang pekerja tidak mendapat kepuasan kerja yang sepatutnya, maka tahap burnout mereka akan meningkat. Selain itu, dapatan kajian ini bertentangan dengan hasil analisis korelasi Roy \& Kumar (2018) yang mendapati terdapat hubungan negatif antara kepuasan kerja dengan sub skala burnout bagi keletihan emosi dan depersonalisasi manakala hubungan positif dicatatkan antara kepuasan kerja dengan pencapaian peribadi.

\section{Metod Kajian}

Kajian ini merupakan kajian yang berbentuk kuantitatif dengan menggunakan kaedah tinjauan. Borang soal selidik dipilih sebagai instrumen kajian dan segala data yang dikumpulkan dianalisis dengan 
kaedah statistik deskriptif dan inferensi. Responden kajian terdiri daripada guru-guru yang mengajar mata pelajaran Pendidikan Jasmani bagi sekolah rendah dan sekolah menengah di Daerah Langkawi. Terdapat dua pemboleh ubah dalam kajian ini iaitu satu pemboleh ubah tidak bersandar dan satu pemboleh ubah bersandar. Pemboleh ubah tidak bersandar ialah kepuasan kerja manakala burnout guru berfungsi sebagai pemboleh ubah bersandar.

\section{Populasi dan sampel kajian}

Populasi ialah jumlah keseluruhan guru Pendidikan Jasmani di Daerah Langkawi manakala sampel ialah subjek atau responden yang terlibat dalam kajian yang dilakukan. Pengkaji menentukan saiz sampel yang diperlukan dalam kajian ini bagi mewakili populasi kajian berpandukan kepada jadual Krejcie dan Morgan dalam Chua (2011). Proses pemilihan dilakukan secara rawak bagi mengelakkan bias dan jumlah responden ialah seramai 101 orang dari jumlah sebenar populasi iaitu seramai 130 orang.

Pengkaji mentadbir soal selidik dengan menggunakan kaedah atas talian disebabkan pandemik Covid19 yang melanda negara sehingga menyebabkan semua institusi pendidikan ditutup bagi mengekang penularan jangkitan virus tersebut. Oleh itu, semua soal selidik ditadbir secara online dengan menggunakan Google Form yang diberikan kepada alamat email responden serta aplikasi Whatsapp peribadi mereka. Seorang responden hanya dibenarkan menjawab soal selidik sekali sahaja.

\section{Instrumen Kajian}

Soal selidik terbahagi kepada 3 bahagian iaitu bahagian A: Demografi Responden, bahagian B: Soal selidik Job Descriptive Index (JDI) dan bahagian C: Soal selidik Maslach Burnout Inventory (MBI). Bagi bahagian A, soal selidik mengandungi lima item yang berkaitan dengan latar belakang responden iaitu jantina, umur, jenis sekolah, opsyen guru, dan pengalaman mengajar. Kajian rintis dijalankan kepada guru yang memenuhi kriteria yang telah ditetapkan untuk mendapatkan kesahan dan kebolehpercayaan soal selidik.

Untuk bahagian B, pengkaji menggunakan alat ukur Job Descriptive Index (JDI) yang dibentuk oleh Cornell (1950). Soal selidik JDI mengandungi 25 item yang telah diubahsuai mengikut kesesuaian dengan populasi kajian. Soal selidik ini terdiri daripada lima aspek utama iaitu suasana kerja itu sendiri, gaji, kenaikan pangkat, penyeliaan dan rakan sekerja. Item dalam soal selidik ini menggunakan skala ' $Y a$ ' jika bersetuju dengan pernyataan tersebut, 'Tidak' jika tidak bersetuju dan 'Tidak Pasti' jika responden tidak pasti dengan item tersebut.

Selain itu, bahagian $\mathrm{C}$ mengandungi soal selidik berkaitan tahap burnout guru yang menggunakan soal selidik Maslach Burnout Inventory (MBI) yang diasaskan oleh Christina Maslach. Soal selidik MBI mempunyai 22 item bagi menggambarkan tiga dimensi utama dalam burnout iaitu keletihan emosi, depersonalisasi dan pencapaian peribadi. Item soal selidik menggunakan skala likert 0 (tidak pernah), 1 (beberapa kali dalam setahun), 2 (sekali dalam sebulan), 3 (beberapa kali dalam sebulan), 4 (sekali dalam seminggu), 5 (beberapa kali dalam seminggu) dan 6 (setiap hari). Tahap burnout guru ditentukan dengan melihat skor mata bagi ketiga-tiga dimensi. Jika skor yang rendah dicapai oleh responden bagi subskala keletihan emosi dan depersonalisasi serta tinggi bagi subskala pencapaian peribadi, maka guru tidak mengalami burnout dan sebaliknya.

Tahap kepuasan kerja dan tahap burnout dibahagikan kepada tiga peringkat iaitu rendah, sederhana dan tinggi berdasarkan pemarkahan yang telah ditetapkan. Bagi kepuasan kerja, markah minimum keseluruhan responden ialah 0 manakala markah maksimum keseluruhan responden ialah 75 . Bagi skor untuk setiap dimensi pula, skor minimum ialah 0 manakala skor maksimum ialah 15 dengan setiap dimensi mengandungi 5 item. Skor burnout juga dibahagikan kepada tiga tahap dengan skor terendah bagi sub skala keletihan emosi dan sub skala depersonalisasi ialah 0 manakala skor tertinggi bagi keletihan emosi ialah (54) dan depersonalisasi (30). Bagi pencapaian peribadi pula, skor minimum ialah 0 manakala skor maksimum ialah 48. Perincian bagi kedua-dua tahap adalah seperti dalam jadual di bawah. 
DOI: https://doi.org/10.47405/mjssh.v6i5.798

Jadual 1: Skor setiap dimensi dan skor keseluruhan tahap kepuasan kerja

\begin{tabular}{ccc}
\hline Tahap & Setiap Dimensi & Skor Keseluruhan \\
\hline Rendah & $0-5$ & $0-25$ \\
Sederhana & $6-10$ & $26-50$ \\
Tinggi & $11-15$ & $51-75$ \\
\hline
\end{tabular}

Jadual 2: Skor keseluruhan tahap burnout

\begin{tabular}{cccc}
\hline Tahap & Keletihan emosi & Depersonalisasi & Pencapaian Peribadi \\
\hline Rendah & $0-17$ & $0-9$ & $0-15$ \\
Sederhana & $18-36$ & $10-20$ & $16-32$ \\
Tinggi & $37-54$ & $21-30$ & $33-48$ \\
\hline
\end{tabular}

Kesemua data dianalisis dengan menggunakan perisian Statistical Package for the Sosial Science (SPSS) versi 22.0 berdasarkan dua kaedah iaitu analisis deskriptif dan analisis inferensi. Bagi analisis deskriptif, pengkaji menggunakan kekerapan, peratusan, min, dan sisihan piawai bagi mengenal pasti tahap kepuasan kerja dan tahap burnout guru PJ. Analisis inferensi pula menggunakan ujian korelasi untuk melihat hubungan antara kedua-dua pemboleh ubah.

Keputusan ujian rintis telah dijalankan kepada 30 orang responden yang memiliki kriteria yang sama seperti yang telah ditetapkan bagi menilai kebolehpercayaan soal selidik. Kedua-dua instrumen soal selidik menunjukkan nilai kebolehpercayaan yang sangat baik dan boleh diterima untuk digunakan dalam kajian ini. Nilai pekali Alpha Cronbach bagi Maslach Burnout Inventory (MBI) untuk sub skala keletihan emosi ialah $0.893(\alpha=.893)$, sub skala depersonalisasi $0.667(\alpha=.667)$ dan sub skala pencapaian peribadi $0.938(\alpha=.938)$. Manakala nilai kebolehpercayaan soal selidik Job Descriptive Index (JDI), nilai pekali Alpha Cronbach ialah $0.845(\alpha=.845)$.

Jadual 3: Ujian Kesahan dan Kebolehpercayaan Instrumen

\begin{tabular}{cccc}
\hline Pemboleh ubah & Jumlah Item & $\begin{array}{c}\text { Nilai } \text { Alpha } \\
\text { Cronbach (A) }\end{array}$ & Interpretasi \\
\hline Kepuasan Kerja & 25 & 0.845 & Baik \\
Keletihan Emosi & 9 & 0.893 & Baik \\
Depersonalisasi & 5 & 0.667 & Boleh Diterima \\
Pencapaian Peribadi & 8 & 0.938 & Sangat Baik \\
\hline
\end{tabular}

\section{Hasil Kajian}

Jumlah responden yang terlibat adalah seramai 101 orang $(n=101)$. Jadual 4 menunjukkan seramai 58 orang $(57.4 \%)$ responden adalah lelaki manakala 43 orang $(42.6 \%)$ responden adalah perempuan. Responden paling ramai adalah dalam lingkungan umur 31 tahun -40 tahun (57.4\%) dan responden paling sedikit adalah dalam lingkungan umur 21 tahun - 30 tahun (6.9\%). Guru sekolah kebangsaan adalah seramai 63 orang (62.4\%) manakala guru sekolah menengah adalah seramai 38 orang (37.6\%).

Selain itu, 47 orang (46.5\%) responden adalah guru opsyen dan selebihnya iaitu 54 orang (53.5\%) adalah guru bukan opsyen. Responden bagi pengalaman mengajar selama 11 tahun - 20 tahun mencatatkan bilangan tertinggi iaitu 46 orang $(45.5 \%)$ manakala paling rendah adalah responden yang mengajar lebih dari 30 tahun iaitu seramai 7 orang $(6.9 \%)$. 
DOI: https://doi.org/10.47405/mjssh.v6i5.798

Jadual 4: Ciri-ciri demografi

\begin{tabular}{clcc}
\hline Ciri-Ciri & Kategori & Kekerapan & Peratusan \\
\hline Jantina & Lelaki & 58 & 57.4 \\
& Perempuan & 43 & 42.6 \\
& JUMLAH & $\mathbf{1 0 1}$ & $\mathbf{1 0 0}$ \\
Umur & 21 - 30 Tahun & 7 & 6.9 \\
& $31-40$ Tahun & 58 & 57.4 \\
& 41-50 Tahun & 27 & 26.7 \\
& 51-60 Tahun & 9 & 8.9 \\
\multirow{5}{*}{ Jenis Sekolah } & JUMLAH & $\mathbf{1 0 1}$ & $\mathbf{1 0 0 . 0}$ \\
& Sekolah Rendah & 63 & 62.4 \\
& Sekolah Menengah & 38 & 37.6 \\
& JUMLAH & $\mathbf{1 0 1}$ & $\mathbf{1 0 0 . 0}$ \\
Pensyen Guru & 47 & 46.5 \\
& Opsyen & 54 & 53.5 \\
& Bukan opsyen & $\mathbf{1 0 1}$ & $\mathbf{1 0 0 . 0}$ \\
& JUMLAH & 37 & 36.6 \\
& < 10 Tahun & 46 & 45.5 \\
& 11 Tahun - 20 Tahun & 11 & 10.9 \\
& 21 Tahun - 30 Tahun & 7 & 6.9 \\
& > 30 Tahun & $\mathbf{1 0 1}$ & $\mathbf{1 0 0 . 0}$ \\
\hline
\end{tabular}

\section{Tahap Kepuasan Kerja dan Burnout}

Jadual 5 menunjukkan dapatan analisis tahap kepuasan kerja berdasarkan jumlah min skor kepuasan kerja bagi setiap dimensi dan secara keseluruhannya. Skor keseluruhan tahap kepuasan kerja guru PJ di Daerah Langkawi menunjukkan berada pada tahap tinggi $(\min =59.56, \mathrm{sp}=$ 10.95) dalam julat $51-75$. Hasil dapatan untuk setiap dimensi menunjukkan min skor bagi dimensi penyeliaan merupakan penyumbang kepada kepuasan kerja yang paling tinggi $(\min =12.99, \mathrm{sp}=$ 3.68) diikuti oleh min skor bagi dimensi rakan sekerja $(\min =12.98, \mathrm{sp}=3.84)$. Ini menunjukkan kebijaksanaan pentadbir menyelia guru dalam sesebuah organisasi merupakan faktor yang paling memberikan kepuasan kerja kepada guru dibantu dengan hubungan yang erat dari rakan sekerja. Dimensi kenaikan pangkat pula mencatatkan min skor terendah iaitu $(\min =9.31, \mathrm{sp}=3.86)$.

Jadual 5: Min Skor Tahap kepuasan kerja

\begin{tabular}{lccc}
\hline Dimensi Kepuasan Kerja & Min & $\begin{array}{c}\text { Sisihan } \\
\text { Piawai }\end{array}$ & Interpretasi \\
\hline Kerja itu sendiri & 12.14 & 3.12 & Tinggi \\
Gaji & 12.15 & 3.38 & Tinggi \\
Kenaikan Pangkat & 9.31 & 3.86 & Sederhana \\
Penyeliaan & 12.99 & 3.68 & Tinggi \\
Rakan Sekerja & 12.98 & 3.84 & Tinggi \\
Skor Keseluruhan & $\mathbf{5 9 . 5 6}$ & $\mathbf{1 0 . 9 5}$ & Tinggi \\
\hline
\end{tabular}

Jadual 6 pula menunjukkan dapatan analisis bagi min skor tahap burnout guru PJ di Daerah Langkawi. Berdasarkan min skor yang telah diterangkan, sub skala keletihan emosi berada pada tahap sederhana $(\min =18.86, \mathrm{sp}=10.25)$ manakala tahap burnout guru bagi sub skala depersonalisasi berada pada tahap rendah $(\min =8.51, \mathrm{sp}=5.59)$. Bagi tahap burnout guru untuk sub skala pencapaian peribadi, guru PJ di Daerah Langkawi mencatatkan tahap tinggi ( $\min =35.43$, $\mathrm{sp}=9.85$ ) yang menunjukkan responden tidak mengalami burnout pada subskala tersebut. 
DOI: https://doi.org/10.47405/mjssh.v6i5.798

Jadual 6: Min Skor Tahap Burnout

\begin{tabular}{lccc}
\hline Subskala Burnout & Min & Sisihan Piawai & Interpretasi \\
\hline Keletihan emosi & 18.86 & 10.25 & Sederhana \\
Depersonalisasi & 8.51 & 5.59 & Rendah \\
Pencapaian Peribadi & 35.43 & 9.85 & Tinggi \\
\hline
\end{tabular}

\section{Hubungan Kepuasan Kerja dengan Burnout}

Jadual 7 menunjukkan skor kepuasan kerja mempunyai hubungan yang signifikan dengan sub skala keletihan emosi dan depersonalisasi manakala bagi sub skala pencapaian peribadi, hubungan yang tidak signifikan dicatatkan. Hasil pengujian mendapati wujud hubungan linear yang songsang atau hubungan negatif yang lemah antara keletihan emosi, $r(99)=-0.212, p<0.05$ dan depersonalisasi, $\mathrm{r}(99)=-0.215, \mathrm{p}<0.05$ dengan kepuasan kerja. Dapatan ini menunjukkan kepuasan kerja guru boleh memberi pengaruh khususnya dalam aspek fizikal dan mental sehingga menyebabkan terjadinya gejala burnout. Bagi hubungan kepuasan kerja dengan sub skala pencapaian peribadi, wujud hubungan negatif yang tidak signifikan, $r(99)=-0.016, \mathrm{p}>0.05)$.

Oleh itu, dapatan ini menunjukkan $\mathrm{H}_{\mathrm{o}}$ iaitu tidak terdapat hubungan yang signifikan antara tahap kepuasan kerja dengan sub skala burnout bagi keletihan emosi $($ sig $=0.034)$ dan depersonalisasi $(\mathrm{sig}=0.031)$ adalah ditolak. Manakala $\mathrm{H}_{\mathrm{o}}$ iaitu tidak terdapat hubungan yang signifikan antara tahap kepuasan kerja dengan sub skala pencapaian peribadi gagal untuk ditolak $(\mathrm{sig}=0.873)$.

Jadual 7: Korelasi antara Tahap Kepuasan Kerja dengan Sub Skala Burnout

\begin{tabular}{lccc}
\hline \multicolumn{1}{c}{ Hubungan } & $\boldsymbol{R}$ & $\begin{array}{c}\text { Tahap Kepuasan Kerja } \\
\text { Tahap } \\
\text { Signifikan }\end{array}$ & Interpretasi \\
\hline Keletihan Emosi & -0.212 & $0.034^{*}$ & $\begin{array}{c}\text { Terdapat hubungan } \\
\text { signifikan } \\
\text { Depersonalisasi }\end{array}$ \\
Pencapaian Peribadi & -0.215 & $0.031^{*}$ & $\begin{array}{c}\text { Terdapat hubungan } \\
\text { signifikan } \\
\text { Tidak terdapat } \\
\text { hubungan signifikan }\end{array}$ \\
\hline
\end{tabular}

"Korelasi adalah signifikan pada aras 0.05

\section{Perbincangan Kajian}

Kajian ini dijalankan untuk mengenal pasti tahap kepuasan kerja dan tahap burnout guru Pendidikan Jasmani (PJ) di Daerah Langkawi serta mengenal pasti hubungan antara kedua-dua pemboleh ubah. Kajian ini adalah antara kajian terawal yang dijalankan di Malaysia untuk melihat hubungan kepuasan kerja dengan burnout guru PJ. Hasil kajian ini secara keseluruhannya mendapati guru-guru PJ di Daerah Langkawi berpuas hati dalam menjalankan tanggungjawab sebagai seorang pendidik kerana mempunyai tahap kepuasan kerja yang tinggi. Dapatan ini selari dengan kajian Ismail et al. (2016) yang mendapati kepuasan kerja guru secara keseluruhannya berada pada tahap yang tinggi di Daerah Ledang, Johor. Tahap kepuasan kerja bagi setiap dimensi pula menunjukkan empat dimensi iaitu kerja itu sendiri, gaji, penyeliaan dan rakan sekerja mencatatkan tahap kepuasan yang tinggi manakala dimensi kenaikan pangkat mencatatkan tahap yang sederhana. Hasil dapatan ini bertentangan dengan kajian yang telah dijalankan oleh Hassan dan Wahab (2017) yang mendapati tahap kepuasan kerja guru berada pada tahap yang sederhana bagi semua dimensi kecuali dimensi rakan sekerja yang mencatatkan tahap yang tinggi. Selain itu, dapatan ini juga bertentangan dengan dapatan Rahman dan Mansor (2018) yang mendapati tahap kepuasan kerja guru bagi semua dimensi berada pada tahap yang sederhana. 
Dimensi penyeliaan merupakan penyumbang utama responden mendapat kepuasan kerja dan diikuti dengan dimensi rakan sekerja. Hasil dapatan ini selari dengan kajian Ismail et al. (2016) yang mendapati faktor penyeliaan dan faktor rakan sekerja merupakan pengaruh utama dalam menentukan kepuasan kerja guru. Hal ini menunjukkan hubungan erat yang wujud dalam sesebuah organisasi dapat membantu guru menjalankan kerja dalam persekitaran yang menyeronokkan tanpa mendapat tekanan dari pihak atasan serta rakan sejawat. Walau bagaimanapun, penelitian perlu dilakukan bagi dimensi kenaikan pangkat kerana responden tidak berpuas hati dalam aspek tersebut. Guru mungkin merasakan beberapa perubahan perlu dilakukan dalam proses kenaikan pangkat bagi mengelakkan bias atau pilih kasih dalam kalangan penjawat awam. Dapatan skor yang tinggi bagi tahap dimensi kerja itu sendiri dan gaji menunjukkan guru berpuas hati dengan kerja mereka serta pendapatan yang diterima. Kekurangan opsyen guru PJ yang menjadi permasalahan di daerah Langkawi tidak memberi kesan kepada guru bukan opsyen untuk tidak mendapat kepuasan kerja yang sepatutnya. Mereka tetap berasa gembira dengan kerja mereka walaupun terpaksa untuk mengajar subjek yang bukan dalam bidang kepakaran. Perkara ini memberikan gambaran bahawa mungkin subjek PJ menyeronokkan dan tidak terlalu susah untuk diajar oleh guru yang bukan opsyen. Gaji juga tidak mendatangkan masalah kepada guru kerana mereka merasakan gaji yang diterima sudah mencukupi untuk kegunaan harian.

Selain itu, hasil kajian juga menunjukkan tahap burnout guru PJ berada pada tahap sederhana bagi sub skala keletihan emosi sama seperti yang dilaporkan dalam kajian Mahmod et al. (2018) yang menunjukkan tahap burnout pensyarah Kolej Komuniti Selandar dan Politeknik Melaka berada pada tahap sederhana bagi sub skala keletihan emosi. Guru PJ mungkin mengalami keletihan dan kelesuan emosi yang sederhana disebabkan bebanan dan tekanan kerja yang memaksa mereka melakukan tugasan yang berlebihan sehingga mereka kehabisan tenaga secara fizikal dan mental. Selain itu, tahap burnout bagi sub skala depersonalisasi menunjukkan tahap yang rendah. Dapatan ini selari dengan kajian Spittle et al. (2015) yang melaporkan guru PJ mengalami tahap rendah bagi sub skala depersonalisasi. Guru tidak mengalami burnout bagi sub skala ini disebabkan oleh suasana kerja guru PJ yang lebih aktif dan interaktif serta melibatkan komunikasi dua hala dengan ramai orang. Guru PJ di Daerah Langkawi mempunyai pencapaian peribadi yang baik dan mereka lebih berpuas hati dengan keupayaan kendiri masing-masing dalam melaksanakan tugas sebagai seorang pendidik. Hal ini boleh dibuktikan apabila dapatan bagi sub skala pencapaian peribadi berada pada tahap tinggi bertentangan dengan kajian Ajang dan Abu Bakar (2019) yang mendapati tahap burnout guru berada pada tahap sederhana bagi sub skala tersebut.

Hasil analisis korelasi Spearman mendapati, terdapat hubungan negatif yang lemah dan signifikan antara tahap kepuasan kerja dengan tahap burnout bagi sub skala keletihan emosi dan depersonalisasi. Hal ini menunjukkan bahawa semakin tinggi tahap kepuasan kerja guru, maka semakin rendah tahap burnout guru bagi sub skala keletihan emosi dan depersonalisasi. Perkara ini boleh dijelaskan apabila guru berasa seronok ketika menjalankan tanggungjawab sebagai pendidikan, emosi dan fizikal mereka tidak terjejas sekaligus membantu guru tersebut mendapatkan kepuasan ketika berkerja. Oleh itu, guru tidak mengalami gejala burnout sehingga mengganggu rutin harian mereka di sekolah. Dapatan kajian ini disokong oleh kajian yang dilakukan Ahmadian et al. (2015) serta Ooi dan Abdullah (2016) yang mendapati terdapat hubungan signifikan yang negatif dan lemah antara kepuasan kerja dengan ketigatiga sub skala dalam burnout. Bagi hubungan antara kepuasan kerja dengan sub skala pencapaian peribadi pula, hasil dapatan menunjukkan tidak terdapat hubungan yang signifikan antara kedua-dua pembolehubah tersebut. Ini menunjukkan, kepuasan kerja tidak mempengaruhi keupayaan profesional guru dalam menjalankan tugas sebagai seorang pendidik. Dapatan ini bertentangan dengan dapatan kajian Roy \& Kumar (2018) dimana hubungan yang positif dicatatkan bagi kepuasan kerja dengan sub skala pencapaian peribadi.

Kajian ini hanya melibatkan guru-guru PJ di Daerah Langkawi, Kedah. Kajian ini juga hanya bertumpu kepada tahap guru itu sendiri berkaitan kepuasan kerja dan burnout guru pada tahun semasa tanpa mengambil kira beberapa faktor lain seperti faktor motivasi dan faktor personaliti guru tersebut. Jumlah responden juga agak terhad kerana hanya melibatkan satu daerah sahaja. Hasil dapatan yang berbeza mungkin akan diperolehi jika guru menjalani rutin harian seperti biasa kerana mereka banyak menghabiskan masa bekerja dari rumah disebabkan oleh pandemik yang melanda negara. Banyak 
program sekolah yang dirancang dan kejohanan-kejohanan sukan dibatalkan dan ini sedikit sebanyak memberi kesan kepada kerja hakiki guru di sekolah.

\section{Kesimpulan}

Burnout sering dikaitkan dengan tekanan yang dialami sehingga tidak mendapat kepuasan kerja yang sepatutnya. Kepuasan kerja seseorang perlu dipenuhi untuk mengelakkan berlakunya gejala burnout. Kajian ini dijalankan untuk mengenal pasti tahap kepuasan kerja dan tahap burnout guru PJ di Daerah Langkawi. Selain itu, kajian ini juga dijalankan untuk melihat hubungan antara kepuasan kerja dengan burnout guru PJ. Dapatan kajian mendapati guru PJ di Daerah Langkawi berpuas hati dengan kerja yang dilakukan. Sokongan serta hubungan yang erat antara majikan dan rakan sekerja dapat menyediakan persekitaran kerja yang menarik dalam membantu guru mengekalkan komitmen dan prestasi yang cemerlang bagi membantu kemenjadian murid secara holistik seiring dengan misi dan visi KPM. Guru PJ di Daerah Langkawi tidak mengalami burnout kecuali sub skala keletihan emosi. Emosi guru perlu diberikan perhatian oleh pihak pengurusan sekolah bagi mengelakkan guru hilang fokus dan tidak mempunyai motivasi sehingga menyebabkan guru mengambil keputusan untuk berhenti dari profesion perguruan.

Memandangkan gejala burnout boleh mendatangkan kesan yang negatif kepada guru dan pihak lain seperti murid, sekolah dan masyarakat, permasalahan ini tidak boleh dipandang enteng. Oleh itu, kajian yang melibatkan sampel yang lebih besar perlu dijalankan bukan sahaja bagi guru yang mengajar subjek Pendidikan Jasmani malah juga boleh melibatkan guru-guru subjek lain. Hal ini dapat membantu pihak atasan sekolah dalam mengenal pasti guru-guru yang mengalami stres di tempat kerja sebelum fenomena ini menjadi lebih getir. Apabila guru mengalami burnout, mereka akan menjadi mudah marah dan sukar mengawal perasaan sehingga dikhuatiri akan mendatangkan kesan yang buruk kepada diri sendiri dan murid. Prestasi guru akan menurun sehingga menimbulkan perasaan kurang senang dalam kalangan rakan sekerja dan mengganggu perancangan yang dilakukan oleh pihak sekolah.

\section{Rujukan}

Affendi, F. (2014). Tahap Kepuasan Kerja dan Komitmen Organisasi dalam Kalangan Guru Kolej Vokasional: Pendekatan Structural Equation Model. Universiti Tun Hussein Onn, Malaysia.

Ahmadian, R., Farshbaf, M., \& Vafaeian, M. (2015). The relationship between burnout and job satisfaction of physical education techers in Shabestar City. Indian Journal of Fundamental and Applied Life Sciences, 5(S2), 1235-1241.

Ajang, L., \& Abu Bakar, K. (2019). Burnout Among Early Childhood Education Teachers: Causes and Implications. International Journal of Education, Psychology and Counseling, 4, 359-372. https://doi.org/10.35631/ijepc.4310031

Al-Adwan, F. E. Z., \& Al-Khayat, M. M. (2017). Psychological Burnout in Early Childhood Teachers: Levels and Reasons. International Education Studies, 10(1), 179-189. https://doi.org/10.5539/ies.v10n1p179

Ali, S. K. S., Hassan, M. F. H., \& Som, H. M. (2017). Tekanan dan Kepuasan Kerja dalam Kalangan Guru Pendidikan Jasmani. Journal of Global Business and Social Entrepreneurship (GBSE), 1, $122-135$.

Awang, Z. (2012). Strategi pengajaran mata pelajaran Pendidikan Jasmani yang berkesan. (Tesis sarjana tidak diterbitkan). Universiti Malaya, Malaysia.

Badawy, S. M. (2015). Egyptian Teachers' Burnout: The Role of Work Environment Characteristics and Job Stress. Journal of Business and Management Sciences, 3(4), 101-110. https://doi.org/10.12691/jbms-3-4-1

Chua, Y. P. (2011). Kaedah Penyelidikan. Selangor: McGraw Hill (Malaysia) Sdn. Bhd.

Esfandiari, R., \& Kamali, M. (2016). On the Relationship between Job Satisfaction, Teacher Burnout, and Teacher Autonomy. Iranian Journal of Applied Language Studies, 8(2), 73-98. 
DOI: https://doi.org/10.47405/mjssh.v6i5.798

Hassan, N., \& Wahab, J. A. (2017). Kepuasan Kerja Dalam Kalangan Guru Di Sekolah Menengah Zon Bangsar. Seminar Pendidikan Serantau Ke-VIII, 401-408. https://seminarserantau2017.files.wordpress.com/2017/09/48-norhazwani-hassan.pdf

Herzberg, F. M. 1959. The Motivation to Work. (2 ${ }^{\text {nd }}$. Ed.). New York: John Wile Y and Sons.

Ineme, K. M., \& Ineme, M. E. (2016). Impact of job satisfaction and burnout on attitudes towards strike action among employees of a Nigerian university. Journal of Higher Education Policy and Management, 38(6), 664-675. https://doi.org/10.1080/1360080X.2016.1211976

Ishak, R. (2015). Hubungan Burnout dengan Kepuasan Kerja dalam kalangan Guru-guru Kemahiran Hidup Bersepadu (KHB) Sekolah Menengah di Daerah Batu Pahat. UniversitiTun Hussien Onn.

Ismail, N. M. Z., Wahab, J. A., \& Hassan, R. M. (2016). Kepuasan Kerja Guru dan Perbezaannya Berdasarkan Pencapaian Sekolah. Jurnal Personalia Pelajar, 19(1), 49-54.

Jamaludin, I. I., \& You, H. W. (2019). Burnout in relation to Gender, Teaching Experience, and Educational Level among Educators. Hindawi Education Research International, 2019, 1-5. https://doi.org/10.1155/2019/7349135

Kariming, N. F., \& Ambotang, A. S. (2018). Hubungan Iklim Sekolah Terhadap Kepuasan Kerja Guru Tingkatan 6 Zon Pantai Timur Sabah. Jurnal Komunikasi Borneo, 6, 53-64.

Kroupis, I., Kouli, O., \& Kourtessis, T. (2019). Physical education teacher's job satisfaction and burnout levels in relation to school's sport facilities. International Journal of Instruction, 12(4), 579-592. https://doi.org/10.29333/iji.2019.12437a

Locke, E. A. (1976) The Nature and Causes of Job Satisfaction. In: Dunnette, M.P., Ed., Handbook of Industrial and Organizational Psychology, Rand McNally, Chicago, 1297-1350.

Louw, D., George, E., \& Esterhuyse, K. (2011). Burnout amongst urban secondary school teachers in Namibia. SA Journal of Industrial Psychology, 37(1), 1-8. https://doi.org/10.4102/sajip.v37i1.1008

Mahmod, N. L., Sarif, S. A., \& Hamzah, H. M. (2018). Tahap Burnout dan Kepuasan Kerja dalam Kalangan Pensyarah di Kolej Komuniti Selandar dan Politeknik Melaka. 1-18.

Mansor, N. A., Ali, J. M., Samin, Z., \& Ma'sum, A. R. (2015). Faktor Kepuasan Kerja dalam Kalangan Pensyarah Kolej Komuniti Ledang dan Kolej Komuniti Pagoh. 1st National Conference on Business \& Innovation 2015, 53(1976), 492-502.

Maslach, C., Schaufeli, W. B., \& Leiter, M. P. (2001). Job burnout. In Annual Review of Psychology (Vol. 52, pp. 397-422). https://doi.org/10.1146/annurev.psych.52.1.397

Matiang'i, J., Makewa, L. N., \& Role, E. (2016). School Factors and Teacher Burnout: A Perception. Open Access Library Journal, 3(e2996), 1-16. https://doi.org/10.4236/oalib.1102996

Mohamad, J., \& Yaacob, N. R. N. (2013). Kajian Tentang Kepuasan Bekerja Dalam Kalangan GuruGuru Pendidikan Khas. Asia Pacific Journal of Educators and Education, 28, 103-115.

Okeke, C. I., \& Mtyuda, P. N. (2017). Teacher Job Dissatisfaction: Implications for Teacher Sustainability and Social Transformation. Journal of Teacher Education for Sustainability, 19(1), 54-68. https://doi.org/10.1515/jtes-2017-0004

Ooi, P. W., \& Abdullah, A. G. K. (2016). Burnout and Job Satisfaction Among Teachers in Chinese Independent Secondary School. International Journal of Elementary Education, 5(5), 47. https://doi.org/10.11648/j.ijeedu.20160505.11

Rahman, N. H. A., \& Mansor, A. N. (2018). Kepuasan Kerja dalam Kalangan Guru Sekolah Agama: Satu Kajian Kes di Sekolah Menengah Agama MAIWP, Wilayah Persekutuan Kuala Lumpur. Prosiding Seminar Kebangsaan Majlis Dekan Pendidikan Universiti Awam 2018, 963-974.

Rohman, M. A. P. (2018). 4.4 peratus guru stres. Berita Harian Online. https://www.bharian.com.my/berita/nasional/2018/08/467001/44-peratus-guru-stres [Retrieved 5 Oktober 2020].

Roy, J. J., \& Kumar, A. M. (2018). Relationship between burnout and job satisfaction among the teachers in engineering institutes. International Journal of Mechanical Engineering and Technology, 9(1), 705-717.

Rusdin, N. M., \& Ali, S. R. (2013). Amalan Dan Cabaran Pelaksanaan Pembelajaran Abad Ke-21. Proceedings of Islamic Civilization and Technology Management, 2013-2025. https://www.tatiuc.edu.my/assets/files/ICTM19-Papers/ICTM-09.pdf

Ryan, S. V., von der Embse, N. P., Pendergast, L. L., Saeki, E., Segool, N., \& Schwing, S. (2017). Leaving the teaching profession: The role of teacher stress and educational accountability policies 
DOI: https://doi.org/10.47405/mjssh.v6i5.798

on turnover intent. Teaching and Teacher Education, 66(August), 1-11. https://doi.org/10.1016/j.tate.2017.03.016

Shen, B., McCaughtry, N., Martin, J., Garn, A., Kulik, N., \& Fahlman, M. (2015). The relationship between teacher burnout and student motivation. British Journal of Educational Psychology, 85(4), 519-532. https://doi.org/10.1111/bjep.12089

Sipon, S. (2010). Stres Kerja Guru - Punca, Kesan dan Strategi Daya Tindak.pdf. In Prosiding Seminar Profesion Perguruan (p. Seminar Profesion Perguruan).

Smetackova, I., Viktorova, I., Pavlas Martanova, V., Pachova, A., Francova, V., \& Stech, S. (2019). Teachers between job satisfaction and burnout syndrome: What makes difference in Czech elementary schools. Frontiers in Psychology, 10(OCT), 1-8. https://doi.org/10.3389/fpsyg.2019.02287

Spittle, M., Kremer, P., \& Steven, S. (2015). Burnout in Secondary School Physical Education. Facta Universitatis - Physical Education and Sport, 13, 33-43.

Sulaiman, M. (2013). Hubungan Tekanan dengan Komitmen dan Kepuasan Kerja dalam Kalangan Guru Program Pendidikan Khas Integrasi Bermasalah Pembelajaran di Empat Buah Sekolah Rendah Daerah Pontian. Universiti Teknologi Malaysia.

Szabo, E., \& Jagodics, B. (2019). Teacher burnout in the light of workplace, organizational, and social factors. Hungarian Educational Research Journal, 9(3), 539-559. https://doi.org/10.1556/063.9.2019.3.44

Teles, R., Valle, A., Rodríguez, S., Piñeiro, I., \& Regueiro, B. (2020). Perceived stress and indicators of burnout in teachers at Portuguese higher education institutions (HEI). International Journal of Environmental Research and Public Health, 17(9), 1-11. https://doi.org/10.3390/ijerph17093248

Tsigilis, N., Zournatzi, E., \& Koustelios, A. (2011). Burnout among physical education teachers in primary and secondary schools. International Journal of Humanities and Social Science, 1(7), 5358. www.ijhssnet.com

Vousiopoulos, S., Kouli, O., Kourtessis, T., Tsitskari, E., \& Dimoulas, D. (2019). Job satisfaction and burnout among greek teachers and physical education teachers: A comparison in minority and public sector schools in thrace. Annals of Applied Sport Science, 7(4), 52-60. https://doi.org/10.29252/aassjournal.786

Zulkafli, N., \& Mahbob, M. H. (2020). Pengaruh Faktor Motivasi Terhadap Prestasi Kerja. Jurnal Wacana Sarjana, 4(June), 1-11. 